\title{
Is there a role of synovial biopsy in drug development?
}

\author{
Maria Filkova ${ }^{1}$, Andrew Cope1, Tim Mant $^{2}$ and James Galloway ${ }^{1 *}$
}

\begin{abstract}
Rheumatoid arthritis (RA) is an autoimmune disease which causes significant pain, joint deformity, functional disability. The pathological hallmark of RA is inflammation of the synovium characterized by involvement of inflammatory and resident stromal cells, soluble mediators and signalling pathways leading to irreversible joint destruction. The treatment goal in RA has evolved over the last decade towards a target of disease remission that is achieved in less than a third of patients in clinical trials. The lack of therapeutic response to current treatments is suggestive of alternative drivers of RA pathogenesis that might serve as promising therapeutic targets. There are data to justify the use of synovial tissue in early drug development. Synovial tissue represents an appropriate compartment to be studied in patients with inflammatory arthritis and provides information that is distinct from peripheral blood. Modern techniques have made the procedure much more accessible and ultrasound guided biopsies represent a safe and acceptable option. Advances in analytic technologies allowing transcriptomic level of analysis can provide unique inside to target organ/tissue following the exposure to investigational medicinal product. However, there are still caveats with regard to both the choice of technique and analytical methods. Therefore the significance of synovial biopsy remains to be determined in future clinical trials. The aim of the current debate is to explore the potential for accessing and evaluating synovial tissue in early drug development, to summarize lessons we have learned from clinical trials and to discuss the challenges that have arisen so far.
\end{abstract}

Keywords: Synovial biopsy, Rheumatoid arthritis, Drug development

\section{Background}

Rheumatoid arthritis (RA) is an autoimmune disease, which causes significant pain, joint deformity, functional disability and a significant overall healthcare burden [1]. The treatment goal in RA has evolved over the last decade towards a target of disease remission. Besides conventional synthetic disease modifying anti-rheumatic drugs (DMARDs), biological agents targeting cytokines (TNF- $\alpha$, IL-1, IL-6) and immune cells (B- and Tlymphocytes) have led to remarkable patient benefits [2]. However, fewer than $30 \%$ of patients in clinical trials achieve disease remission [3].

Although many new agents for treating RA have been evaluated in phase II/III clinical trials in recent years, progression to later phase clinical research or licencing has been limited by concerns about adverse events or

\footnotetext{
* Correspondence: james.galloway@kcl.ac.uk

${ }^{1}$ Academic Department of Rheumatology, Weston Education Centre, King's

College London, Cutcombe Road, SE5 9RJ London, UK

Full list of author information is available at the end of the article
}

lack of therapeutic effect [4]. For example, fostamatinib, a selective inhibitor of spleen tyrosine kinase (SYK), suppressed clinical arthritis and bone erosions in a mouse model of arthritis [5]. However, following four phase II and three phase III clinical trials involving 3200 patients with active RA it was felt that the agent was not worth taking forward to market due to lack of efficacy [4]. The reasons for drugs failing are invariably complex. However, a lack of adequate information about human pharmacodynamics during the early stages of drug development represents a key factor. We hypothesize that early mechanism of action studies with a detailed understanding of the pharmacology of the drug within the target tissue may greatly facilitate progress through clinical development $[6,7]$.

The pathological hallmark of RA is inflammation of the synovium. This involves a crosstalk between heterogeneous inflammatory and resident stromal cells as well as presence of many soluble mediators and signalling pathways leading to irreversible joint destruction [8]. 
Given this complexity, the lack of therapeutic response to current treatments is suggestive of alternative drivers of RA pathogenesis that might serve as promising therapeutic targets $[9,10]$.

In this debate we aimed to explore the potential for accessing and evaluating synovial tissue in early drug development (Fig. 1), to summarize lessons we have learned from clinical trials and to discuss the challenges that have arisen so far.

\section{Discussion}

\section{The case for using synovial biopsy in drug development}

In phase I clinical trials, safety and tolerability of a new drug is assessed in healthy volunteers adopting a 'maximum tolerated dose' approach that seeks to establish drug safety, tolerability, pharmacokinetics and pharmacodynamics of a drug and identify a suitable dose for phase II studies. Phase II looks for signals to support the idea that the drug is efficacious. Early signal of pharmacodynamic effect in target or surrogate tissue may support the idea that the drug has efficacy in patients and may help to establish dosing regimen as shown in oncology trials $[7,11]$. Based on phase II outcomes, one or two doses are then tested in phase III trials that will ultimately confirm efficacy in a larger target population and provide the information required for licensure. In addition to time needed for the drug development, it is important to acknowledge that the journey of a drug through these phases costs upwards of $£ 40$ million in the current era, with an average drug taking over 7 years to make the transition from phase 1 through to market [12].
Many of the newer agents used for treating rheumatic diseases are monoclonal antibodies (mAb) that have no 'maximum tolerated dose'. The general approach to selecting a safe human starting dose for mAbs has significantly changed following a series of severe, life threatening adverse events observed during a first-in-human (FIH) clinical trial [13]. The concept of a minimal anticipated biological effect level was coined to provide an understanding of the minimum dose at which pharmacodynamic activity might be anticipated in humans, using data derived from pre-clinical studies in animals or in vitro studies [14].

To complicate matters, the pharmacokinetic properties of a mAb may differ greatly between healthy volunteers and patients with the target disease because the pharmacokinetics may depend upon the levels of target ligand present and the role of the target molecule in normal and pathophysiological condition $[15,16]$. Healthy volunteers may express the therapeutic target to much lesser extent than the patients or may not express it at all. Therefore choosing doses for subsequent study is more challenging as too high a dose may lead not only to early toxicity, but also the delayed effects of immune suppression (e.g. infection or cancer). Conversely, selecting too low a dose may lead to a failure to demonstrate efficacy and result in inappropriately stopping further study of a potentially useful agent. For example, levels of IL-17, which contributes to the pathogenesis of RA, are extremely low or undetectable in healthy humans while IL-17 is elevated in sera and synovial fluid of patients with RA and IL-17 is present at site of inflammation in

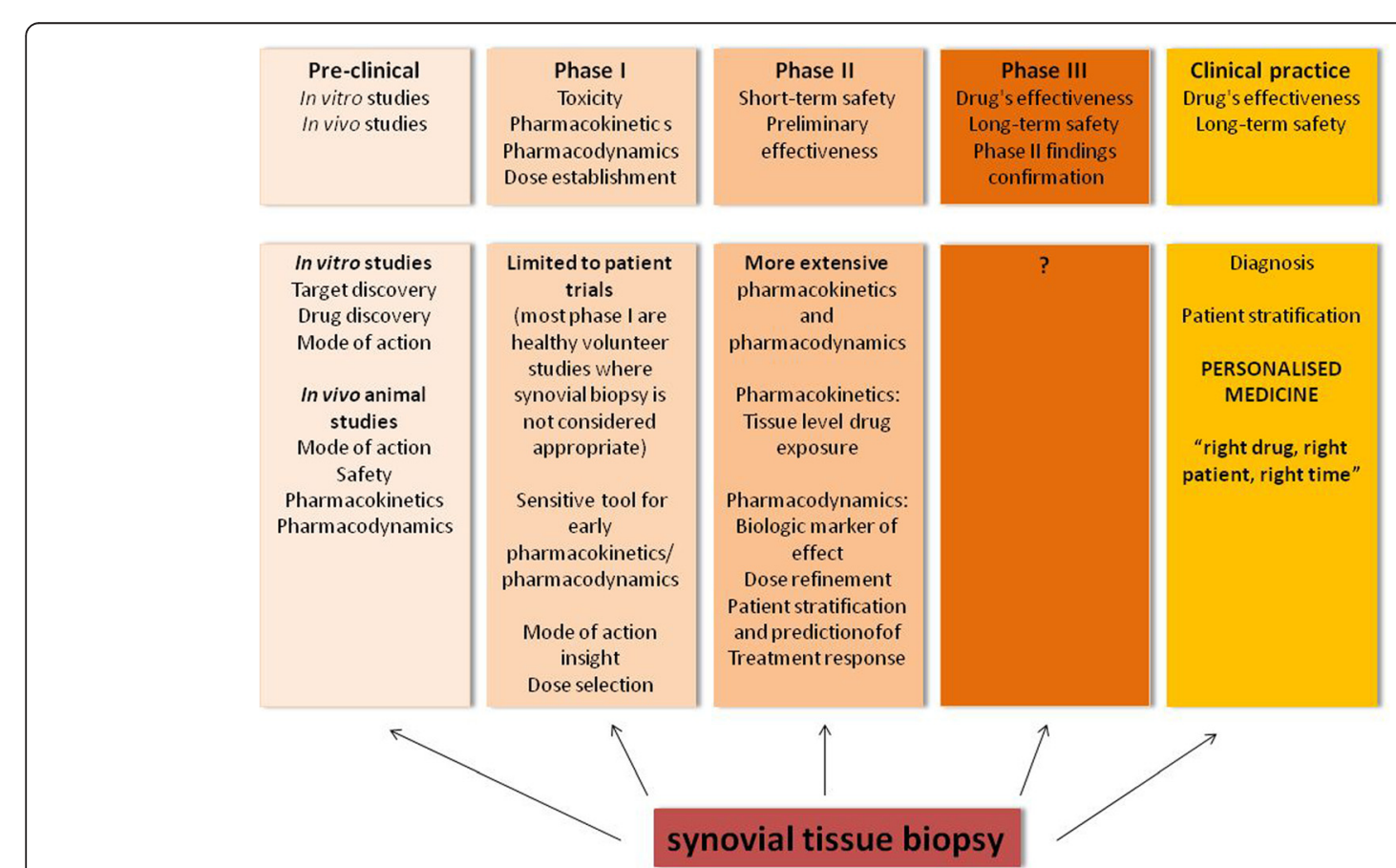

Fig. 1 Validated and potential use of synovial tissue biopsy in all stages of drug development and clinical practice 
RA synovial tissue $[15,17]$. Therefore, an FIH trial of an anti-interleukin-17 monoclonal antibody performed in patients with RA instead of healthy volunteers was a logical approach [18].

Pharmacodynamic effects of investigational medicinal product (IMP) in RA can be analyzed either in peripheral blood (plasma/serum/blood cells) or, with respect to RA pathogenesis, in synovial tissue. Studies have shown that expression of biomarkers in synovial tissue may be independent of peripheral blood [19, 20].

Natural biological variability in disease activity and synovial tissue could be an important aspect in long-term trials. In comparison to the variations observed in clinical assessment, laboratory assessment including synovial tissue changes are more stable and less susceptible to placebo response [21-23]. Analysis of synovial tissue during clinical trials appears a sensible approach to document changes directly at the site of inflammation and joint destruction. Published analysis of synovium has been mostly limited to histology or single gene transcript [24, 25]. These approaches, although providing clinically useful information, were not granular enough to inform early phase trial development. Studies of synovial biopsies using state-of-the-art technologies and composite ontogenetic/ pathway analysis of gene clusters have been shown to be more informative and relevant when compared to analysis of individual markers [20, 26].

Finally, clinical outcomes require longer time follow up and larger patient numbers that are permitted in early phase studies [27]. Therefore there is an urgent need to better quantify drug effect using alternative approaches in small proof-of-principle studies [6]. The earlier on in clinical development a signal of pharmacodynamics effect can be identified, fewer unnecessary people will be recruited to trials, and novel drugs will have a higher chance of succeeding through later phases.

Considering that synovial hyperplasia and its aggressive potential are the hallmark of RA, analysis of early pharmacodynamic effects of IMP in synovial tissue in early phase clinical trials may be of great interest.

\section{Synovial biopsy technique and safety - new approach on board}

In order to obtain synovial tissue from affected joint, either an open method using surgical intervention or minimally invasive techniques may be used. The latter have been increasingly utilised due to minimal burden on patients' well being [24, 28].

A widely used method, a gold standard of synovial tissue biopsy enabling visualisation of the joint, is to acquire tissue at arthroscopy [27]. Although arthroscopic biopsies are usually logistically more challenging, as they require theatre settings and tend to be performed on larger joints, smaller procedure rooms or the outpatient clinic setting appeared feasible and accessible to rheumatologists [29]. The knee is the commonest site of arthroscopy, although other smaller joints are accessible to arthroscopy when an arthroscope of smaller diameter is used. This is essential at early stages of the disease when predominantly hand and wrist joints are affected. An important advantage of arthroscopy is direct visualisation of the examined joint enabling macroscopic evaluation of synovial tissue and cartilage and obtaining adequate amount of tissue for further sample processing [24].

Development and widespread use of ultrasound by rheumatologists has supported the use of ultrasoundguided synovial biopsies, merging the minimally invasive needle biopsy with the advantage of visualized guidance [30]. Although concerns about the validity of tissue sampling for further sample processing and use other than immunohistochemistry (e.g. molecular biology) have been raised in the past [27], current knowledge provides a firm evidence of good safety profile, tolerability and reproducibility of high quality of sample collection even from the small joints that are most frequently affected joints in RA [30]. While previous studies obtained 6-8 samples per procedure, retrieving up to 12-15 samples was shown to be tolerated by patients $[28,30]$.

In summary, recent advances in imaging, minimally invasive biopsy procedures and tissue analysis offer a unique opportunity to use synovial tissue in early drug development given the discovery of new drivers and novel therapies in RA. Learning from the oncologists' approach of performing whole genome transcriptomics on very small samples of tissue in proof-of-concept studies [31], there is the potential to adopt this approach in RA.

\section{Obtaining high quality tissue and potential pitfalls}

A major challenge of synovial tissue biopsies is obtaining representative samples suitable for further analysis. Several pitfalls during the process of tissue biopsy including selection of site of biopsy deserve consideration.

First, it is essential to identify a joint with inflamed synovium for biopsy. RA is a polyarticular disease affecting predominantly hand joints. However, these may not often be suitable for synovial biopsy despite availability of minimally invasive techniques. Therefore the question arises as to whether there are differences between the synovium in the large and small joints. In general, cell numbers present in synovial biopsies from knee joint or small joint are comparable with a strong correlation for the number of macrophages, $\mathrm{T}$ cells and plasma cells along with IL-6 expression in the sublining layer across joints. These results suggest that the inflammation in one inflamed joint is generally representative of that in other inflamed joints from the same patient. In contrast, hyperplasia of intimal lining appears to depend on local processes as the numbers of intimal macrophages or 
synovial fibroblasts in the lining layer do not correlate between the different joints [32].

However, data obtained from open procedures (e.g. joint replacement surgery) have revealed that significant tissue heterogeneity is apparent within a single joint. It was shown that number of differentially expressed genes between biopsies from the same patient was about three times larger in orthopaedic than in arthroscopic biopsies because open tissue biopsy included heterogeneous quality samples from both inflamed and non-inflamed regions [33]. Arthroscopic biopsies do allow direct visualisation of the joint and therefore permit a targeted biopsy of affected tissue, although despite this, arthroscopic biopsies still do not guarantee adequate tissue for analysis [24,34].

Ultrasound has a distinct advantage in the identification of synovial tissue for biopsy by allowing assessment of both synovial thickening and tissue vascularity, which can be considered a surrogate for the direct visualisation of inflamed tissue. Pre-biopsy grey-scale US assessment of synovitis predicts synovial tissue quantity/quality for histological and RNA analyses in contrast to power Doppler [30].

Several studies analyzed histological variability between multiple specimens obtained during one biopsy procedure. Histological analysis of tissue specimens obtained from different areas the knee joint, including those of apparent maximal and minimal involvement, showed wide range of histological scores that reflects natural biological variability [34, 35]. Other studies showed similar pattern of cell infiltrates and expression of selected mediators at mRNA or protein level when compared synovial tissue originating from the junction or suprapatellar pouch [36, 37]. However, it is preferential to obtain sections derived from multiple sites within one joint for analysis based on natural variation within synovial tissue $[38,39]$.

Synovial tissue analysis in trials - which method is the best? As summarized above, the optimal approach to obtain representative samples is to directly visualize inflamed tissue arthroscopically or with ultrasound. Direct visualization during biopsy minimizes sampling error, enables acquisition of biopsies from precise locations within joints and provides reproducible good quality tissues. Available techniques for synovial tissue analysis will now be summarized (Fig. 2).

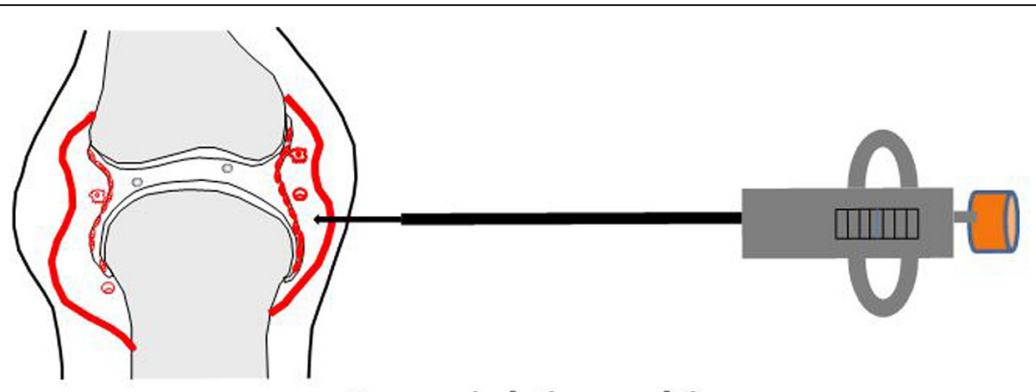

Synovial tissue biopsy

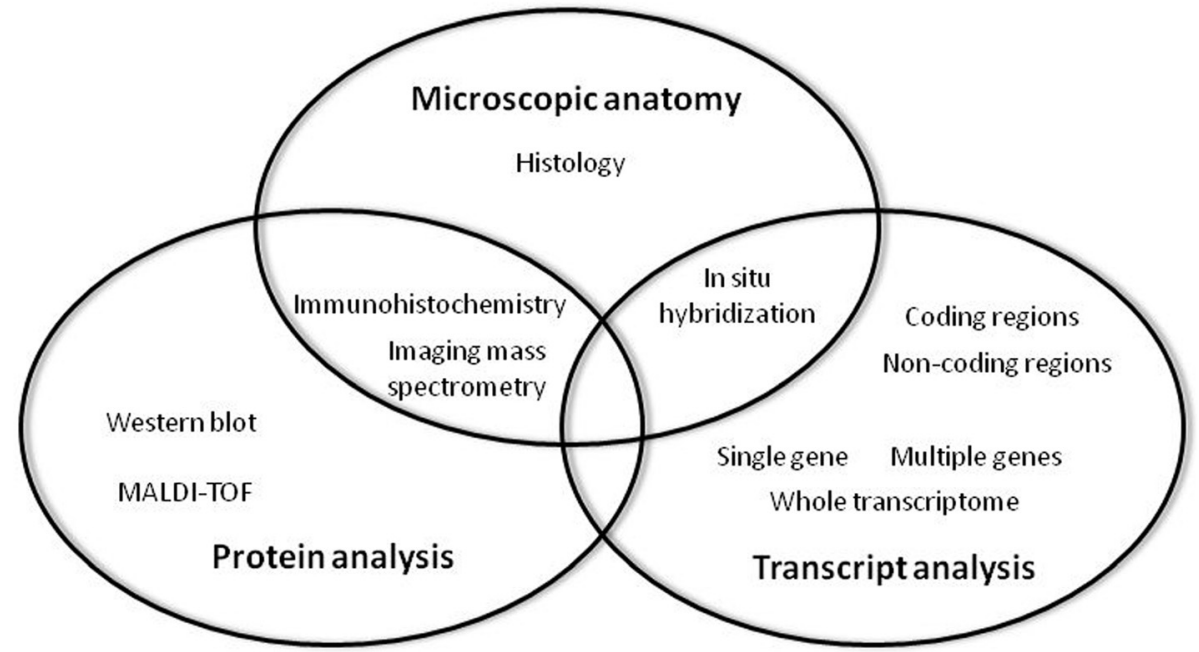

Fig. 2 Methods of synovial tissue analysis with implications for drug development 


\section{Histological analysis and immunohistochemistry (IHC)}

The typical feature of RA synovium is synovial thickening in the lining layer due to infiltration of monocytes/macrophages and excessive proliferation of synovial fibroblasts, in the sublining layer by marked cellular infiltrate, which includes synovial fibroblasts, macrophages, CD4+ and CD8+ T cells, B cells, plasma cells, dendritic and mast cells, in addition to increased vascularity due to enhanced angiogenesis [40]. Immune cells can be grouped into follicular structures (follicular synovitis, mostly B cells) in $30-40 \%$ of patients or be randomly distributed within the sublining layer (diffuse synovitis, predominantly CD68+ cells). In contrast, another type known as pauci-immune synovitis shows hardly any infiltrating immune-cells and may be present in active disease [41].

Histology and IHC enable visualization of cell/protein markers expression and distribution in synovial tissue. An accurate estimate of the overall joint should be satisfactorily provided by analysis of cumulative area of $2.5 \mathrm{~mm}^{2}$ from at least 3 biopsy specimens when sample is obtained during arthroplasty, arthroscopy or blind synovial tissue biopsy from small or large joints [42, 43]. However, 6-8 tissue samples are usually obtained for further analysis [28, 30]. US-guided biopsy was shown to approach $92.5-100 \%$ success in acquisition of histologically reliable tissues [30, 42].

Methods used for quantitative analysis of IHC data have both advantages and limitations [24, 38, 39]. One potential error may occur due to lack of internal normalization or non-specific accumulation of pigmented precipitate detected by enzymatic processes [39]. Although manual cell counting is considered a standard histological analysis, it is time consuming and faces several other pitfalls, e.g. observer bias, limited number and selection of fields to be analyzed that may cause significant limitation in large clinical trials. Widely used semi-quantitative analysis and latest techniques using computer based digital image analysis may minimize these errors, are acceptable for whole tissue analysis of widespread targets, lack field selection errors and bias may be minimized by using grading scales and analyses performed by independent readers.

Semi-quantitative histopathological scoring system (from 0 , absent to 3 , strong) was used to evaluate 3 features of chronic synovitis: enlargement of lining cell layer, cellular density of synovial stroma and leukocytic infiltrate. The sum provided the synovitis score $(0-1$, no synovitis; $2-4$, low-grade synovitis; $5-9$, high-grade synovitis) that showed $61.7 \%$ sensitivity and $96.1 \%$ specificity for RA-related high-grade synovitis and contributed to the diagnostics of rheumatic and non-rheumatic joint diseases [44].

\section{Western blot and mass spectrometry}

The western blot is an analytical technique used to detect specific proteins of interest in tissue homogenate or extract but has limited value in clinical trials. Instead, analyses using mass spectrometry may become a promising method to analyze proteome from whole tissue extracts. Matrix assisted laser desorption/ionization combined with time-of-flight detection (MALDI-TOF) was recently shown to distinguish different subgroups of juvenile idiopathic arthritis [45]. Imaging mass spectrometry that combines morphology and mass spectrometry has been used to illustrate various mass spectra generated from proteins expressed in RA and osteoarthritis synovial tissue [46]. In theory MALDI-TOF also offers an opportunity to quantitatively assess tissue level drug exposure directly, although this has not previously been done. Mass cytometry, previously used for cell suspensions, has recently been coupled with IHC and immunocytochemical methods with highresolution laser ablation to CyTOF mass cytometry [47]. Although this method has only been applied to malignant tissue so far, it is a candidate approach that could identify over 100 protein markers in conjunction with a CyTOF machine enabling high-dimensional, single-cell analysis of cell type and state, cell interactions and tissue structure in future targeted diagnosis and therapies [47].

\section{In situ hybridization}

Similar to IHC, in situ hybridization shows a target of interest at the transcriptional level (messenger RNA, mRNA) and enables visualisation of mRNA distribution within tissue. Information obtained by in situ hybridization can be reliably confirmed at the protein level by IHC [48]. Albeit that this method is powerful enough to detect even small non-coding RNAs such as miRNAs, it is time consuming, requires multiple steps to be optimized for every single target or tissue and, like IHC, enables detection of only limited number of genes.

\section{Single/multiple gene analysis and transcriptome profiling}

Gene expression technology has expanded enormously in recent years and enables analysis of single genes, groups of genes or whole genome wide expression profiles including protein-coding or non-coding regions, although sufficient tissue is needed for RNA extraction. Needle arthroscopy using 2-mm grasping forceps and obtaining 6 biopsy specimens provided at least $15-50 \mathrm{mg}$ for further RNA analysis [49]. Other studies using needle arthroscopy approach showed that at least 4 biopsy samples provided 1-2 $\mu$ g of total RNA [50, 51]. Yield from ultrasound guided synovial tissue biopsy taking 6 samples with 16/14G quick core needles provided at least $10 \mathrm{mg}$ of synovial tissue for RNA isolation, with a median RNA yield $0.54-0.89 \mu \mathrm{g} / 10 \mathrm{mg}$ tissue. The yield varied according to joint size with a tendency for lower yields obtained from small joints [30]. General, > 1 ug of RNA is needed for transcriptomic studies, particularly RNA-sequencing [52], which is generally at the threshold of total RNA obtained from synovial tissue biopsies. A 
relatively new approach to overcome this issue is a low-input 5'- or 3'-RNA-sequencing, where the terminal 300-500 bp of either the 5'- or 3'-end of the mRNA is sequenced instead of the entire transcript and low quantities of starting material (as low as $1 \mathrm{ng}$ total RNA) can be used [53].

Considering serial tissue biopsies for clinical trial purposes, similar numbers of biopsies as well as RNA yield was obtained in subsequent biopsies 12 weeks apart and demonstrated evidence of tissue level pharmacodynamic response [30]. These data suggest that ultrasoundguided synovial tissue biopsies have the potential to be taken forward as a method of choice in the experimental setting associated with drug development.

In keeping with sampling errors discussed above, transcriptome profiling also carries a risk of error due to biological or technical variability [54]. The manner by which these factors influence gene expression profiles remains unsure as changes in transcriptome can occur very rapidly: while one study emphasized the major impact of biological variability (age, sex, time of the day, cellular composition), another study showed that technical variability is of greater importance [54, 55]. Also, intra-patient variations in biopsies are smaller than inter-patient variations, reflecting unique mRNA signatures of each patient rather than tissue heterogeneity [56].

Microarray technology, that uses selected probes placed on solid matrix, is limited by the reliance upon existing knowledge about genome sequence, high background noise and a limited dynamic range [31]. In contrast, RNA sequencing enables studying the whole transcriptome including gene boundaries and introns, splicing diversity as well as detection of small RNAs in a high-throughput and quantitative manner [57].

\section{Transcriptome interpretation}

Studies using state-of-the-art technologies and composite ontogenetic/pathway analysis $\mathrm{s}$ have been shown to be more informative and relevant compared to analysis of individual markers [24-26]. Such comprehensive analysis in tissue/blood may indentify single genes or gene combinations/subsets that may have a predictive/diagnostic value and may be taken forward for further validation [58-60]. For example, a set of 20 genes selected from microarray analysis of white blood cells had $90 \%$ sensitivity and $70 \%$ specificity whilst a combination of only 8 genes had $80 \%$ sensitivity and $100 \%$ specificity to distinguish RA responders or non-responders to infliximab [58]. However, expression profiles, providing e.g. a gene expression signature predictive of therapeutic response, are often inconsistent across studies [59]. Protocol standardization from preanalytical phase until data analysis is therefore crucial for obtaining reliable, consistent and reproducible data [25, 27]. Also, selection of the same tissue type, patients and clinical parameters are important to be considered when different studies are compared [61]. Importantly, genome-wide expression profiling, changes in transcriptome, pathway/ontology analysis, and comparison between different cell types/compartments may unravel complex molecular interactions and reflect responses to therapy.

\section{What have we learned from histopathological analysis of synovial biopsies in clinical trials?}

As mentioned above, the increasing pressure to obtain accurate and reliable outcome data in early phase clinical trials draws attention to synovial biopsies. Recognition of markers of early drug response at synovial tissue level would be of great value in proof-of-concept studies and would help to make early go/no go decisions on progression of the drug to next phase level. Also, multiple studies using IHC have revealed association between baseline synovial tissue biomarkers, their change upon therapeutic intervention and future disease response. Much of the data were generated after exposure to very well known, newly introduced and experimental drugs, and are summarized in Table 1 . The overview is based on a complex literature review providing results of original studies and summaries of systematic reviews.

These data must be compared and interpreted with caution given the different timelines, disease characteristics of patient groups and immunolabeling, e.g. B cell markers CD19, CD22 and CD20 that are not jointly expressed during the maturation of B cells [62-65]. As some data are in contrast to changes documented in peripheral blood, composition of synovial tissue infiltrates and expression of mediators may drive local inflammation or be associated with early relapse of RA and underscore the importance of looking at synovial tissue $[62,64]$. Also, the absence of clinical effect of a study drug/placebo is accompanied by the lack of changes in sequential biopsies [21, 66-68]. This supports the importance of synovial tissue analysis during treatment that may be more sensitive than clinical assessment.

\section{Synovial transcriptome: a new biomarker?}

Data on complex gene expression analysis on RA, osteoarthritis and healthy synovial tissue suggested that this approach could be taken forward to test transcriptome responses following treatment at synovial tissue level $[69,70]$. Both immune and stromal cells contribute to tissue heterogeneity resulting in clusters of differentially expressed genes in keeping with different pathophysiologic processes across patients [20, 41, 71]. A group of RA patients with high inflammatory gene expression pattern indicated involvement of immunity and defence pathways and activation of $\mathrm{B}$ and $\mathrm{T}$ cells while the other group showed predominantly involvement of cell-communication, developmental and fibroblast-dedifferentiation pathways 
Table 1 Overview of immunohistopathological data obtained from small proof-of-concept studies using synovial biopsies in RA

\begin{tabular}{|c|c|c|c|}
\hline Drug & $\begin{array}{l}\text { Timing of } \\
\text { biopsies }\end{array}$ & Key finding & Reference \\
\hline $\begin{array}{l}\text { DMARDs/anti-TNF/ } \\
\text { experimental }\end{array}$ & $2-16$ weeks & $\begin{array}{l}\text { Number of CD68+ macrophages in sublining synovial layer is } \\
\text { a good biomarker of therapeutic response. }\end{array}$ & [76-79] \\
\hline Methotrexate & 16 weeks & $\begin{array}{l}\text { Decrease in the numbers of inflammatory cells, including CD3+ } \\
\text { and CD8+ T cells, CD38+ plasma cells, CD68+ macrophages } \\
\text { (lining layer), inflammatory and destructive mediators } \\
\text { (Ki67, IL-1 } \beta \text {, TNF-a, E-selectin, ICAM-1, VCAM-1, MMP-1). } \\
\text { Responders displayed a reduction in the expression of all ICAM-1, } \\
\text { VCAM-1, TNF-a and IL-1 } \beta \text {. }\end{array}$ & {$[80,81]$} \\
\hline Methotrexate & 12 weeks & $\begin{array}{l}\text { No change in synovial hyperplasia, lymphoplasmocytic infiltrate, } \\
\text { CD68+ macrophages, CD3+ T cells and CD138+ plasma cells }\end{array}$ & [50] \\
\hline Leflunomide & 16 weeks & $\begin{array}{l}\text { Decrease in the numbers CD68+ macrophages (sublining), } \\
\text { inflammatory and destructive mediators (ICAM-1, VCAM-1, MMP-1). } \\
\text { Responders displayed a reduction in the expression of ICAM-1, } \\
\text { VCAM-1 and TNF-a. }\end{array}$ & [81] \\
\hline Prednisolone & $24 \mathrm{~h}$ & $\begin{array}{l}\text { Decrease in the expression of TNF-a (lining and sublining), IL-8 (lining), } \\
\text { as well as reduced synovial fluid IL-8 levels. Change in TNF-a correlated } \\
\text { with clinical response to, and subsequent relapse after therapy }\end{array}$ & [82] \\
\hline Prednisolone & 2 weeks & $\begin{array}{l}\text { Reduction in the number of sublining synovial macrophages, a trend } \\
\text { toward decreased infiltration by CD4+ T cells, CD38+ plasma cells, } \\
\text { and CD55+ fibroblast-like synoviocytes }\end{array}$ & [76] \\
\hline Infliximab (3 mg/kg) & $\begin{array}{l}48 \mathrm{~h} / \\
4 \text { weeks }\end{array}$ & $\begin{array}{l}\text { Reduced number of CD68+ intimal macrophages after } 48 \mathrm{~h} \text {, a trend } \\
\text { to decreased amount of CD38+ plasma cells, CD3+ T cells, sublining } \\
\text { CD68+ macrophages after } 48 \mathrm{~h} / 4 \text { weeks. Decreased numbers of CD3+, } \\
\text { CD38+ and both intinal and sublining CD68+ cells were observed in } \\
\text { clinical responders after } 4 \text { weeks. }\end{array}$ & [23] \\
\hline Infliximab (10 mg/kg) & 2 weeks & $\begin{array}{l}\text { Reduction in the numbers of infiltrating synovial CD3+ T cells, CD22+ B cells, } \\
\text { CD68+ macrophages and in the expression of IL-8, MCP-1 and TNF-a. High } \\
\text { levels of synovial TNF-a prior to treatment may predict responsiveness to therapy. }\end{array}$ & {$[83,84]$} \\
\hline Rituximab & 4 weeks & Incomplete depletion of CD22+ B cells, no correlation with the change in DAS28. & [62] \\
\hline Rituximab & $\begin{array}{l}4 \text { weeks } \\
16 \text { weeks }\end{array}$ & $\begin{array}{l}\text { CD19+ B cells significantly but incompletely decreased at } 4 \text { weeks, with } \\
\text { further reduction at } 16 \text { weeks in some patients. Decrease in CD68+ } \\
\text { macrophages at } 4 \text { and } 16 \text { weeks, CD3+ T cells decreased at } 16 \text { weeks. } \\
\text { The reduction of CD138+ plasma cells predicted clinical improvement } \\
\text { at } 24 \text { weeks. }\end{array}$ & [64] \\
\hline Rituximab & 12 weeks & $\begin{array}{l}\text { Depletion of CD20+ B cells, trend to decrease in CD68+ macrophages. } \\
\text { No correlations between changes in CD20+ or CD68+ and changes in } \\
\text { the DAS28. Positivity for circulating IgM ACPA, in combination with a } \\
\text { high infiltration of CD79a + B cells is a predictor of clinical outcome } \\
\text { after rituximab. }\end{array}$ & {$[51,65]$} \\
\hline Tocilizumab & 12 weeks & $\begin{array}{l}\text { Decrease in synovial hyperplasia, lymphoplasmocytic infiltrate, CD68+ } \\
\text { macrophages, CD3+ T cells and CD138+ plasma cells }\end{array}$ & [50] \\
\hline Anakinra + pegsunercept & $\begin{array}{l}4 \text { weeks } \\
52 \text { weeks }\end{array}$ & $\begin{array}{l}\text { Decrease in number of CD3+ T cells and TGF } \beta \text { expression as biomarker } \\
\text { therapeutic response at weeks } 4 \text { and } 52 \text { of combination therapy. } \\
\text { Baseline CD3+ and sublining CD68+ infiltration, VEGF and TGF } \beta \\
\text { expression were predictive of subsequent structural outcome } \\
\text { at } 6 \text { or } 12 \text { months. }\end{array}$ & [19] \\
\hline CCR1 antagonist & 2 weeks & $\begin{array}{l}\text { Reduction in overall cellularity, number of CD4+ and CD8+ T cells, } \\
\text { CD68+ macrophages and the number of CCR1+ cells. }\end{array}$ & [22] \\
\hline ReclL-10 & 12 weeks & $\begin{array}{l}\text { No significant change in number of inflammatory cells or in the } \\
\text { scores for the expression of cytokines. }\end{array}$ & [85] \\
\hline IL-1 receptor antagonist & 24 weeks & Reduction in intimal and sublining CD68+ macrophages and CD3+ lymphocytes. & [86] \\
\hline Anti-CCL2 antibody & 6 weeks & No immunohistologic changes. & [66] \\
\hline C5aR-antagonis & 4 weeks & No immunohistologic changes. & [67] \\
\hline $\begin{array}{l}\text { IFN- } \beta(18 / 36 / 54 \text { million } \\
\text { IU/week) }\end{array}$ & $\begin{array}{l}4 \text { weeks } \\
12 \text { weeks }\end{array}$ & $\begin{array}{l}\text { Decrease in number of CD3+ T cells at } 4 \text { weeks and CD38+ plasma cells at } 12 \text { weeks along with } \\
\text { changes of several inflammatory and destructive molecules (e.g. MMP-1, IL-6 or IL-1 } \beta \text { ). }\end{array}$ & {$[87]$} \\
\hline IFN- $\beta$ (6.6/132 $\mu \mathrm{g} /$ week) & 24 weeks & No changes in synovial tissue infiltrates. & [68] \\
\hline
\end{tabular}


[9, 20, 41]. Similarly, gene expression in synovial tissue from patients with early RA identified at least two patterns of synovitis, one of which resembled long-standing RA [72]. In addition, distinct baseline synovial gene expression signature reflecting phenotypes of RA synovium (lymphoid, myeloid, low inflammatory, fibroid) may be predictive of treatment response: synovial myeloid, but not lymphoid, gene signature expression was higher in patients with good compared with poor response to anti-TNFa therapy [71]. These data suggest that RA patients with different pathway activation may need different therapeutic approaches. Examples of comprehensive gene expression analysis aiming for individualized therapy and understanding of mode of action of novel therapies are summarized in Table 2.

Importantly, the differences between study designs and selection of patients should be considered. For example, treatment with methotrexate, tocilizumab and rituximab had similar molecular effects on transcriptomic changes (albeit of different magnitudes) in the RA synovium, which were distinct from the molecular changes induced by adalimumab $[50,51,73]$. It is important to notice that patients included in these trials were at different stages of the disease, since patients on tocilizumab or methotrexate were treatment naive, patients on adalimumab had failed DMARD therapy and patients commencing rituximab were both DMARDs anti-TNF failures. Although to date transcriptome analysis has been directed towards prediction of clinical response, its greatest strength may lie in helping understand of drug mode of action.

\section{Is transcriptome analysis in peripheral blood superior to synovial tissue?}

Compared to synovial biopsy, obtaining peripheral blood to explore new biomarkers of treatment response may be convenient due to the quick and non-invasive approach. However, there is evidence that transcriptome analysis in peripheral blood and synovial tissue may be of different value:

Table 2 Overview of gene expression analysis obtained from small proof-of-concept studies using synovial biopsies in RA

\begin{tabular}{|c|c|c|c|}
\hline Drug & Timing of biopsies & Key finding & Reference \\
\hline Infliximab & Baseline & $\begin{array}{l}\text { Differential baseline gene expression in responders and non-responders. } \\
\text { Overexpression of genes involved in T-cell mediated immunity, cell } \\
\text { surface receptor mediated signal transduction, major histocompatibility } \\
\text { complex II (MHCII)-mediated immunity, cell adhesion, cytokine and } \\
\text { chemokine mediated signalling, cell adhesion mediated signalling, } \\
\text { signal transduction, and macrophage-mediated immunity identified } \\
\text { in responders. }\end{array}$ & {$[88]$} \\
\hline Infliximab & 9 weeks & $\begin{array}{l}\text { Unique baseline transcriptome in all patients. } 279 \text { differentially expressed } \\
\text { genes between good responders and non-responders. Significant change } \\
\text { in expression of } 115 \text { genes in the good responding group involved in } \\
\text { immune response, cell communication, signal transduction and chemotaxis. }\end{array}$ & {$[56]$} \\
\hline Adalimumab & 12 weeks & $\begin{array}{l}\text { Deregulated baseline expression of } 439 \text { genes involved in cell cycle } \\
\text { and immune responses in good vs. poor responders. Differential } \\
\text { expression of } 632 \text { genes enrolled in cell division, signal transduction, } \\
\text { antigen processing/presentation, T-cell activation, and apoptosis } \\
\text { upon adalimumab treatment in a group of good responders. }\end{array}$ & [73] \\
\hline Rituximab & 12 weeks & $\begin{array}{l}\text { Deregulated baseline expression of } 2458 \text { genes involved in immunoglobulin } \\
\text { clusters, antigen processing and presentation via MHCII in non-responders } \\
\text { vs. responders. Treatment with rituximab resulted in downregulation of } \\
220 \text { genes enriched in immunoglobulin clusters, chemotaxis, leukocyte } \\
\text { activation and immune responses; upregulation of } 329 \text { genes involved } \\
\text { in cell development and wound healing. }\end{array}$ & {$[51]$} \\
\hline Rituximab & $\begin{array}{l}12 \text { weeks } \\
21 \text { months }\end{array}$ & $\begin{array}{l}\text { Baseline differential expression of genes involved in T cell and macrophage } \\
\text { function, remodelling and interferon-a biology between non-responders } \\
\text { vs. responders at months } 3,9 \text { and } 21 \text {. Downregulation of CD20 at } 3 \\
\text { and } 12 \text { months, differential expression of multiple genes involved in } \\
\text { B and T cell biology at } 21 \text { months (e.g. CD27, CD38, CD8, CD52, CTLA4, } \\
\text { CD122, FOXP3, IL-6, IL-12, IL-13, IL-17RA, IL-23a, IL-32, CCL5, MMP3, FASLG) }\end{array}$ & [89] \\
\hline Tocilizumab & 12 weeks & $\begin{array}{l}\text { Downregulation of } 3413 \text { genes involved in cytokine/chemokine pathways } \\
\text { and T cell activation, upregulation of } 3270 \text { genes involved in healing } \\
\text { process. Downregulation of genes involved in induction of apoptosis } \\
\text { and myeloid cell differentiation, and upregulation of genes involved in } \\
\text { regulation of Ras protein signal transduction and ubiquitin-dependent } \\
\text { protein catabolic processes observed in responders achieving remission } \\
\text { at } 6 \text { months. }\end{array}$ & {$[50]$} \\
\hline Methotrexate & 12 weeks & $\begin{array}{l}\text { Downregulation of } 586 \text { genes enriched in T cell activation and immune } \\
\text { response pathways, upregulation of } 610 \text { genes. Downregulation of genes } \\
\text { enrolled in cell division in responders achieving remission at } 6 \text { months. }\end{array}$ & {$[50]$} \\
\hline
\end{tabular}


While gene expression profiling in RA synovial tissue mentioned above [20] revealed 2 groups of patients based on differential involvement of molecular pathways in keeping with the immunohistopathological picture, gene expression profiles in peripheral blood did not reflect the differential tissue pathology.

Gene expression analysis using a microarray approach was performed on RNA from peripheral blood mononuclear cells (PBMC) $72 \mathrm{~h}$ after a single dose of etanercept [74]. Although a combination of 46 genes at baseline level did not predict therapeutic response, the change in their expression was associated with disease activity at 3 months. Pathway analysis in PBMC revealed TNF $\alpha$ and IL- 6 related downstream changes in responders while TNF- $\alpha$ related mechanisms were detected in non-responders suggesting differential regulation in non-responders [74]. Also, infliximab dampened immune responses in PBMC one month after first dose [75]. It was shown that all RA patients have a similar magnitude of down-regulation of genes involved in inflammation, angiogenesis and $\mathrm{T}$ and $\mathrm{B}$ cell activation irrespective of clinical response evaluated after 16 weeks, highlighting that the transcript changes observed in peripheral blood correlate less well with clinical response compared to synovium.

\section{Conclusions}

There is grooving evidence to justify the use of synovial tissue in early drug development. Synovial tissue represents an appropriate compartment to be studied in patients with inflammatory arthritis and provides information that is distinct from peripheral blood in the context of RA. Modern techniques have made the procedure much more accessible and ultrasound guided biopsies represent a safe and acceptable option. Advances in analytic technologies allowing transcriptomic level of analysis can provide unique inside to target organ/tissue following the exposure to IMP. However, there are still caveats with regard to both the choice of technique and analytical methods. Therefore the significance of synovial biopsy remains to be determined in future clinical trials.

\section{Ethics and consent to participate Not Applicable.}

\section{Consent to publish \\ Not Applicable.}

\section{Availability of data and materials}

The authors don't provide any original data. All references supporting authors' conclusions are addressed within the manuscript.

\section{Abbreviations}

CyTOF: Cytometry by Time of Flight; DMARDs: disease modifying anti-rheumatic drugs; FIH: first-in-human trial; IFN: interferon; IHC: immunohistochemistry;
IL: interleukin; IMP: investigational medicinal product; mAb: monoclonal antibody; PBMC: peripheral blood mononuclear cells; MALDI-TOF: matrix assisted laser desorption/ionization combined with time-of-flight detection; RA: rheumatoid arthritis; RNA: ribonucleic acid.

\section{Competing interests}

The authors declare that they have no competing interests.

\section{Authors' contributions}

All authors were involved in the conception and design of the review. MF and JG drafted the manuscript, AC and TM revised the manuscript critically for the content. All authors gave final approval of the version to be published and agreed to be accountable for all aspects of the manuscript in ensuring that questions related to the accuracy or integrity of any part of the work are appropriately investigated and addressed.

\section{Acknowledgements}

None

Funding

This study was supported by EATC grant.

\section{Author details}

${ }^{1}$ Academic Department of Rheumatology, Weston Education Centre, King's College London, Cutcombe Road, SE5 9RJ London, UK. ²Quintiles Drug Research Unit at Guy's Hospital, London, UK

Received: 6 November 2015 Accepted: 9 April 2016

Published online: 19 April 2016

\section{References}

1. Klareskog L, Catrina Al, Paget S. Rheumatoid arthritis. Lancet. 2009;373(9664): 659-72.

2. Schoels M, Aletaha D, Smolen JS, Wong JB. Comparative effectiveness and safety of biological treatment options after tumour necrosis factor alpha inhibitor failure in rheumatoid arthritis: systematic review and indirect pairwise meta-analysis. Ann Rheum Dis. 2012;71(8):1303-8.

3. Scott DL. Biologics-based therapy for the treatment of rheumatoid arthritis. Clin Pharmacol Ther. 2012;91(1):30-43.

4. Scott IC, Scott DL. Spleen tyrosine kinase inhibitors for rheumatoid arthritis: where are we now? Drugs. 2014;74(4):415-22

5. Pine PR, Chang B, Schoettler N, Banquerigo ML, Wang S, Lau A, Zhao F, Grossbard EB, Payan DG, Brahn E. Inflammation and bone erosion are suppressed in models of rheumatoid arthritis following treatment with a novel Syk inhibitor. Clin Immunol. 2007:124(3):244-57.

6. $\quad$ Ang JE, Kaye S, Banerji U. Tissue-based approaches to study pharmacodynamic endpoints in early phase oncology clinical trials. Curr Drug Targets. 2012;13(12): 1525-34.

7. Banerji U, O'Donnell A, Scurr M, Pacey S, Stapleton S, Asad Y, Simmons L, Maloney A, Raynaud F, Campbell M, et al. Phase I pharmacokinetic and pharmacodynamic study of 17-allylamino, 17-demethoxygeldanamycin in patients with advanced malignancies. J Clin Oncol. 2005;23(18):4152-61.

8. Muller-Ladner U, Pap T, Gay RE, Neidhart M, Gay S. Mechanisms of disease: the molecular and cellular basis of joint destruction in rheumatoid arthritis. Nat Clin Pract Rheumatol. 2005;1(2):102-10.

9. van der Pouw Kraan TC, van Gaalen FA, Huizinga TW, Pieterman E, Breedveld FC, Verweij CL. Discovery of distinctive gene expression profiles in rheumatoid synovium using cDNA microarray technology: evidence for the existence of multiple pathways of tissue destruction and repair. Genes Immun. 2003;4(3):187-96.

10. Smolen JS, Aletaha D, Koeller M, Weisman MH, Emery P. New therapies for treatment of rheumatoid arthritis. Lancet. 2007;370(9602):1861-74.

11. Agulnik M, da Cunha SG, Hedley D, Nicklee T, Dos Reis PP, Ho J, Pond GR, Chen $\mathrm{H}$, Chen $\mathrm{S}$, Shyr $\mathrm{Y}$, et al. Predictive and pharmacodynamic biomarker studies in tumor and skin tissue samples of patients with recurrent or metastatic squamous cell carcinoma of the head and neck treated with erlotinib. J Clin Oncol. 2007:25(16):2184-90.

12. Paul SM, Mytelka DS, Dunwiddie CT, Persinger CC, Munos BH, Lindborg SR, Schacht AL. How to improve R\&D productivity: the pharmaceutical industry's grand challenge. Nat Rev Drug Discov. 2010;9(3):203-14. 
13. Suntharalingam G, Perry MR, Ward S, Brett SJ, Castello-Cortes A, Brunner MD, Panoskaltsis N. Cytokine storm in a phase 1 trial of the anti-CD28 monoclonal antibody TGN1412. N Engl J Med. 2006;355(10):1018-28.

14. Muller PY, Milton M, Lloyd P, Sims J, Brennan FR. The minimum anticipated biological effect level (MABEL) for selection of first human dose in clinical trials with monoclonal antibodies. Curr Opin Biotechnol. 2009;20(6):722-9.

15. Ziolkowska M, Koc A, Luszczykiewicz G, Ksiezopolska-Pietrzak K, Klimczak E, Chwalinska-Sadowska H, Maslinski W. High levels of IL-17 in rheumatoid arthritis patients: IL-15 triggers in vitro IL-17 production via cyclosporin Asensitive mechanism. J Immunol. 2000;164(5):2832-8.

16. Tranter E, Peters G, Boyce M, Warrington S. Giving monoclonal antibodies to healthy volunteers in phase 1 trials: is it safe? Br J Clin Pharmacol. 2013; 76(2):164-72.

17. Chabaud M, Durand JM, Buchs N, Fossiez F, Page G, Frappart L, Miossec P. Human interleukin-17: A T cell-derived proinflammatory cytokine produced by the rheumatoid synovium. Arthritis Rheum. 1999;42(5):963-70.

18. Genovese MC, Van den Bosch F, Roberson SA, Bojin S, Biagini IM, Ryan P, Sloan-Lancaster J. LY2439821, a humanized anti-interleukin-17 monoclonal antibody, in the treatment of patients with rheumatoid arthritis: A phase I randomized, double-blind, placebo-controlled, proof-of-concept study. Arthritis Rheum. 2010;62(4):929-39.

19. Rooney T, Roux-Lombard P, Veale DJ, FitzGerald O, Dayer JM, Bresnihan B. Synovial tissue and serum biomarkers of disease activity, therapeutic response and radiographic progression: analysis of a proof-of-concept randomised clinical trial of cytokine blockade. Ann Rheum Dis. 2010;69(4):706-14.

20. van Baarsen LG, Wijbrandts CA, Timmer TC, van der Pouw Kraan TC, Tak PP, Verweij CL. Synovial tissue heterogeneity in rheumatoid arthritis in relation to disease activity and biomarkers in peripheral blood. Arthritis Rheum. 2010;62(6):1602-7.

21. Baeten D, Houbiers J, Kruithof E, Vandooren B, Van den Bosch F, Boots AM, Veys EM, Miltenburg AM, De Keyser F. Synovial inflammation does not change in the absence of effective treatment: implications for the use of synovial histopathology as biomarker in early phase clinical trials in rheumatoid arthritis. Ann Rheum Dis. 2006;65(8):990-7.

22. Haringman JJ, Kraan MC, Smeets TJ, Zwinderman KH, Tak PP. Chemokine blockade and chronic inflammatory disease: proof of concept in patients with rheumatoid arthritis. Ann Rheum Dis. 2003;62(8):715-21.

23. Smeets TJ, Kraan MC, van Loon ME, Tak PP. Tumor necrosis factor alpha blockade reduces the synovial cell infiltrate early after initiation of treatment, but apparently not by induction of apoptosis in synovial tissue. Arthritis Rheum. 2003;48(8):2155-62

24. Gerlag DM, Tak PP. How to perform and analyse synovial biopsies. Best Pract Res Clin Rheumatol. 2013;27(2):195-207.

25. van Baarsen $L G$, Bos $C L$, van der Pouw Kraan TC, Verweij $C L$. Transcription profiling of rheumatic diseases. Arthritis Res Ther. 2009;11(1):207.

26. Yue L, Reisdorf WC. Pathway and ontology analysis: emerging approaches connecting transcriptome data and clinical endpoints. Curr Mol Med. 2005, 5(1):11-21.

27. van de Sande MG, Gerlag DM, Lodde BM, van Baarsen LG, Alivernini S, Codullo V, Felea I, Vieira-Sousa E, Fearon U, Reece R, et al. Evaluating antirheumatic treatments using synovial biopsy: a recommendation for standardisation to be used in clinical trials. Ann Rheum Dis. 2011;70(3):423-7.

28. Koski JM, Helle M. Ultrasound guided synovial biopsy using portal and forceps. Ann Rheum Dis. 2005;64(6):926-9.

29. Kane D, Veale DJ, FitzGerald O, Reece R. Survey of arthroscopy performed by rheumatologists. Rheumatology. 2002:41(2):210-5.

30. Kelly S, Humby F, Filer A, Ng N, Di Cicco M, Hands RE, Rocher V, Bombardieri M, D'Agostino MA, McInnes IB, et al. Ultrasound-guided synovial biopsy: a safe, well-tolerated and reliable technique for obtaining high-quality synovial tissue from both large and small joints in early arthritis patients. Ann Rheum Dis. 2015;74(3):611-17.

31. Clarke PA, te Poele R, Workman P. Gene expression microarray technologies in the development of new therapeutic agents. Eur J Cancer. 2004;40(17):2560-91

32. Kraan MC, Reece RJ, Smeets TJ, Veale DJ, Emery P, Tak PP. Comparison of synovial tissues from the knee joints and the small joints of rheumatoid arthritis patients: Implications for pathogenesis and evaluation of treatment. Arthritis Rheum. 2002;46(8):2034-8.

33. Lindberg J, af Klint E, Ulfgren AK, Stark A, Andersson T, Nilsson P, Klareskog $L$, Lundeberg J. Variability in synovial inflammation in rheumatoid arthritis investigated by microarray technology. Arthritis Res Ther. 2006;8(2):R47.
34. Lindblad S, Hedfors E. Intraarticular variation in synovitis. Local macroscopic and microscopic signs of inflammatory activity are significantly correlated. Arthritis Rheum. 1985;28(9):977-86.

35. Rooney M, Condell D, Quinlan W, Daly L, Whelan A, Feighery C, Bresnihan B. Analysis of the histologic variation of synovitis in rheumatoid arthritis. Arthritis Rheum. 1988;31(8):956-63.

36. Smeets TJ, Kraan MC, Galjaard S, Youssef PP, Smith MD, Tak PP. Analysis of the cell infiltrate and expression of matrix metalloproteinases and granzyme $B$ in paired synovial biopsy specimens from the cartilage-pannus junction in patients with RA. Ann Rheum Dis. 2001;60(6):561-5.

37. Kirkham B, Portek I, Lee CS, Stavros B, Lenarczyk A, Lassere M, Edmonds J. Intraarticular variability of synovial membrane histology, immunohistology, and cytokine mRNA expression in patients with rheumatoid arthritis. J Rheumatol. 1999;26(4):777-84.

38. Smith MD, Baeten D, Ulfgren AK, Mclnnes IB, Fitzgerald O, Bresnihan B, Tak PP, Veale D, group Ossi. Standardisation of synovial tissue infiltrate analysis: how far have we come? How much further do we need to go? Ann Rheum Dis. 2006;65(1):93-100.

39. Boyle DL, Rosengren S, Bugbee W, Kavanaugh A, Firestein GS. Quantitative biomarker analysis of synovial gene expression by real-time PCR. Arthritis Res Ther. 2003;5(6):R352-60.

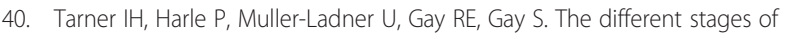
synovitis: acute vs chronic, early vs late and non-erosive vs erosive. Best Pract Res Clin Rheumatol. 2005;19(1):19-35.

41. Pitzalis C, Kelly S, Humby F. New learnings on the pathophysiology of RA from synovial biopsies. Curr Opin Rheumatol. 2013;25(3):334-44.

42. Scire CA, Epis O, Codullo V, Humby F, Morbini P, Manzo A, Caporali R, Pitzalis C, Montecucco C. Immunohistological assessment of the synovial tissue in small joints

in rheumatoid arthritis: validation of a minimally invasive ultrasound-guided synovial biopsy procedure. Arthritis Res Ther. 2007;9(5):R101.

43. Bresnihan B, Cunnane G, Youssef P, Yanni G, Fitzgerald O, Mulherin D. Microscopic measurement of synovial membrane inflammation in rheumatoid arthritis: proposals for the evaluation of tissue samples by quantitative analysis. Br J Rheumatol. 1998;37(6):636-42.

44. Krenn V, Morawietz L, Burmester GR, Kinne RW, Mueller-Ladner U, Muller B, Haupl T. Synovitis score: discrimination between chronic low-grade and high-grade synovitis. Histopathology. 2006;49(4):358-64.

45. Finnegan S, Robson J, Scaife C, McAllister C, Pennington SR, Gibson DS, Rooney ME. Synovial membrane protein expression differs between juvenile idiopathic arthritis subtypes in early disease. Arthritis Res Ther. 2014;16(1):R8

46. Kriegsmann M, Seeley EH, Schwarting A, Kriegsmann J, Otto M, Thabe H, Dierkes B, Biehl C, Sack U, Wellmann A, et al. MALDI MS imaging as a powerful tool for investigating synovial tissue. Scand J Rheumatol. 2012;41(4):305-9

47. Giesen C, Wang HA, Schapiro D, Zivanovic N, Jacobs A, Hattendorf B, Schuffler PJ, Grolimund D, Buhmann JM, Brandt S, et al. Highly multiplexed imaging of tumor tissues with subcellular resolution by mass cytometry. Nat Methods. 2014;11(4):417-22.

48. Judex M, Neumann E, Lechner S, Dietmaier W, Ballhorn W, Grifka J, Gay S, Scholmerich J, Kullmann F, Muller-Ladner U. Laser-mediated microdissection facilitates analysis of area-specific gene expression in rheumatoid synovium. Arthritis Rheum. 2003;48(1):97-102.

49. Lindberg J, Wijbrandts CA, van Baarsen LG, Nader G, Klareskog L, Catrina A, Thurlings R, Vervoordeldonk M, Lundeberg J, Tak PP. The gene expression profile in the synovium as a predictor of the clinical response to infliximab treatment in rheumatoid arthritis. PLoS One. 2010:5(6):e11310.

50. Ducreux J, Durez P, Galant C, Nzeusseu Toukap A, Van den Eynde B, Houssiau FA, Lauwerys BR. Global molecular effects of tocilizumab therapy in rheumatoid arthritis synovium. Arthritis Rheumatol. 2014;66(1):15-23.

51. Gutierrez-Roelens I, Galant C, Theate I, Lories RJ, Durez P, Nzeusseu-Toukap A, Van den Eynde B, Houssiau FA, Lauwerys BR. Rituximab treatment induces the expression of genes involved in healing processes in the rheumatoid arthritis synovium. Arthritis Rheum. 2011;63(5):1246-54.

52. Adiconis X, Borges-Rivera D, Satija R, DeLuca DS, Busby MA, Berlin AM, Sivachenko A, Thompson DA, Wysoker A, Fennell T, et al. Comparative analysis of RNA sequencing methods for degraded or low-input samples. Nat Methods. 2013;10(7):623-9.

53. Beck $A H$, Weng $Z$, Witten DM, Zhu S, Foley JW, Lacroute $P$, Smith $C L$, Tibshirani $R$, van de Rijn M, Sidow A, et al. 3'-end sequencing for 
expression quantification (3SEQ) from archival tumor samples. PLoS One. 2010;5(1):e8768.

54. Bryant PA, Smyth GK, Robins-Browne R, Curtis N. Technical variability is greater than biological variability in a microarray experiment but both are outweighed by changes induced by stimulation. PLoS One. 2011;6(5):e19556.

55. Whitney AR, Diehn M, Popper SJ, Alizadeh AA, Boldrick JC, Relman DA, Brown PO. Individuality and variation in gene expression patterns in human blood. Proc Natl Acad Sci U S A. 2003;100(4):1896-901.

56. Lindberg J, Af Klint E, Catrina Al, Nilsson P, Klareskog L, Ulfgren AK, Lundeberg J. Effect of infliximab on mRNA expression profiles in synovial tissue of rheumatoid arthritis patients. Arthritis Res Ther. 2006;8(6):R179.

57. Wang Z, Gerstein M, Snyder M. RNA-Seq: a revolutionary tool for transcriptomics. Nat Rev Genet. 2009;10(1):57-63.

58. Lequerre T, Gauthier-Jauneau AC, Bansard C, Derambure C, Hiron M, Vittecoq O, Daveau M, Mejjad O, Daragon A, Tron F, et al. Gene profiling in white blood cells predicts infliximab responsiveness in rheumatoid arthritis. Arthritis Res Ther. 2006;8(4):R105.

59. Toonen EJ, Gilissen C, Franke B, Kievit W, Eijsbouts AM, den Broeder AA, van Reijmersdal SV, Veltman JA, Scheffer H, Radstake TR, et al. Validation study of existing gene expression signatures for anti-TNF treatment in patients with rheumatoid arthritis. PLoS One. 2012;7(3):e33199.

60. Stuhlmuller B, Haupl T, Hernandez MM, Grutzkau A, Kuban RJ, Tandon N, Voss JW, Salfeld J, Kinne RW, Burmester GR. CD11C as a transcriptional biomarker to predict response to anti-TNF monotherapy with adalimumab in patients with rheumatoid arthritis. Clin Pharmacol Ther. 2010;87(3):311-21.

61. Haupl T, Stuhlmuller B, Grutzkau A, Radbruch A, Burmester GR. Does gene expression analysis inform us in rheumatoid arthritis? Ann Rheum Dis. 2010; 69 Suppl 1:i37-42.

62. Vos K, Thurlings RM, Wijbrandts CA, van Schaardenburg D, Gerlag DM, Tak PP. Early effects of rituximab on the synovial cell infiltrate in patients with rheumatoid arthritis. Arthritis Rheum. 2007:56(3):772-8.

63. Thurlings RM, Vos K, Gerlag DM, Tak PP. Disease activity-guided rituximab therapy in rheumatoid arthritis: the effects of re-treatment in initial nonresponders versus initial responders. Arthritis Rheum. 2008;58(12):3657-64.

64. Thurlings RM, Vos K, Wijbrandts CA, Zwinderman AH, Gerlag DM, Tak PP. Synovial tissue response to rituximab: mechanism of action and identification of biomarkers of response. Ann Rheum Dis. 2008;67(7):917-25.

65. Teng YK, Levarht EW, Hashemi M, Bajema IM, Toes RE, Huizinga TW, van Laar JM. Immunohistochemical analysis as a means to predict responsiveness to rituximab treatment. Arthritis Rheum. 2007:56(12):3909-18.

66. Haringman JJ, Gerlag DM, Smeets TJ, Baeten D, van den Bosch F, Bresnihan B, Breedveld FC, Dinant HJ, Legay F, Gram H, et al. A randomized controlled trial with an anti-CCL2 (anti-monocyte chemotactic protein 1) monoclonal antibody in patients with rheumatoid arthritis. Arthritis Rheum. 2006;54(8): 2387-92.

67. Vergunst CE, Gerlag DM, Dinant H, Schulz L, Vinkenoog M, Smeets TJ, Sanders ME, Reedquist KA, Tak PP. Blocking the receptor for C5a in patients with rheumatoid arthritis does not reduce synovial inflammation. Rheumatology. 2007:46(12):1773-8,

68. van Holten J, Pavelka K, Vencovsky J, Stahl H, Rozman B, Genovese M, Kivitz AJ, Alvaro J, Nuki G, Furst DE, et al. A multicentre, randomised, double blind, placebo controlled phase II study of subcutaneous interferon beta-1a in the treatment of patients with active rheumatoid arthritis. Ann Rheum Dis. 2005;64(1):64-9.

69. Zanders ED, Goulden MG, Kennedy TC, Kempsell KE. Analysis of immune system gene expression in small rheumatoid arthritis biopsies using a combination of subtractive hybridization and high-density CDNA arrays. J Immunol Methods. 2000;233(1-2):131-40.

70. Devauchelle V, Marion S, Cagnard N, Mistou S, Falgarone G, Breban M, Letourneur F, Pitaval A, Alibert O, Lucchesi C, et al. DNA microarray allows molecular profiling of rheumatoid arthritis and identification of pathophysiological targets. Genes and immunity. 2004;5(8):597-608.

71. Dennis Jr G, Holweg CT, Kummerfeld SK, Choy DF, Setiadi AF, Hackney JA, Haverty PM, Gilbert H, Lin WY, Diehl L, et al. Synovial phenotypes in rheumatoid arthritis correlate with response to biologic therapeutics. Arthritis Res Ther. 2014;16(2):R90.

72. Tsubaki T, Arita N, Kawakami T, Shiratsuchi T, Yamamoto H, Takubo N, Yamada K, Nakata S, Yamamoto S, Nose M. Characterization of histopathology and gene-expression profiles of synovitis in early rheumatoid arthritis using targeted biopsy specimens. Arthritis Res Ther. 2005;7(4):R825-36
73. Badot V, Galant C, Nzeusseu Toukap A, Theate I, Maudoux AL, Van den Eynde BJ, Durez P, Houssiau FA, Lauwerys BR. Gene expression profiling in the synovium identifies a predictive signature of absence of response to adalimumab therapy in rheumatoid arthritis. Arthritis Res Ther. 2009;11(2):R57.

74. Koczan D, Drynda S, Hecker M, Drynda A, Guthke R, Kekow J, Thiesen HJ. Molecular discrimination of responders and nonresponders to anti-TNF alpha therapy in rheumatoid arthritis by etanercept. Arthritis Res Ther. 2008;10(3):R50.

75. van Baarsen LG, Wijbrandts CA, Gerlag DM, Rustenburg F, van der Pouw Kraan TC, Dijkmans BA, Tak PP, Verweij CL. Pharmacogenomics of infliximab treatment using peripheral blood cells of patients with rheumatoid arthritis. Genes Immun. 2010;11(8):622-9.

76. Gerlag DM, Haringman JJ, Smeets TJ, Zwinderman AH, Kraan MC, Laud PJ, Morgan S, Nash AF, Tak PP. Effects of oral prednisolone on biomarkers in synovial tissue and clinical improvement in rheumatoid arthritis. Arthritis Rheum. 2004;50(12):3783-91.

77. Haringman JJ, Gerlag DM, Zwinderman AH, Smeets TJ, Kraan MC, Baeten D, Mclnnes IB, Bresnihan B, Tak PP. Synovial tissue macrophages: a sensitive biomarker for response to treatment in patients with rheumatoid arthritis. Ann Rheum Dis. 2005;64(6):834-8.

78. Bresnihan B, Pontifex E, Thurlings RM, Vinkenoog M, El-Gabalawy H, Fearon U, Fitzgerald O, Gerlag DM, Rooney T, van de Sande MG, et al. Synovial tissue sublining CD68 expression is a biomarker of therapeutic response in rheumatoid arthritis clinical trials: consistency across centers. J Rheumatol. 2009:36(8):1800-2.

79. Bresnihan B, Baeten D, Firestein GS, Fitzgerald OM, Gerlag DM, Haringman JJ, McInnes IB, Reece RJ, Smith MD, Ulfgren AK, et al. Synovial tissue analysis in clinical trials. J Rheumatol. 2005;32(12):2481-4.

80. Dolhain RJ, Tak PP, Dijkmans BA, De Kuiper P, Breedveld FC, Miltenburg AM Methotrexate reduces inflammatory cell numbers, expression of monokines and of adhesion molecules in synovial tissue of patients with rheumatoid arthritis. Br J Rheumatol. 1998;37(5):502-8.

81. Kraan MC, Reece RJ, Barg EC, Smeets TJ, Farnell J, Rosenburg R, Veale DJ, Breedveld FC, Emery P, Tak PP. Modulation of inflammation and metalloproteinase expression in synovial tissue by leflunomide and methotrexate in patients with active rheumatoid arthritis. Findings in a prospective, randomized, double-blind, parallel-design clinical trial in thirty-nine patients at two centers. Arthritis Rheum. 2000;43(8):1820-30.

82. Youssef PP, Haynes DR, Triantafillou S, Parker A, Gamble JR, RobertsThomson PJ, Ahern MJ, Smith MD. Effects of pulse methylprednisolone on inflammatory mediators in peripheral blood, synovial fluid, and synovial membrane in rheumatoid arthritis. Arthritis Rheum. 1997;40(8):1400-8.

83. Taylor PC, Peters AM, Paleolog E, Chapman PT, Elliott MJ, McCloskey R, Feldmann M, Maini RN. Reduction of chemokine levels and leukocyte traffic to joints by tumor necrosis factor alpha blockade in patients with rheumatoid arthritis. Arthritis Rheum. 2000;43(1):38-47.

84. Ulfgren AK, Andersson U, Engstrom M, Klareskog L, Maini RN, Taylor PC. Systemic anti-tumor necrosis factor alpha therapy in rheumatoid arthritis down-regulates synovial tumor necrosis factor alpha synthesis. Arthritis Rheum. 2000;43(11):2391-6.

85. Smeets TJ, Kraan MC, Versendaal J, Breedveld FC, Tak PP. Analysis of serial synovial biopsies in patients with rheumatoid arthritis: description of a control group without clinical improvement after treatment with interleukin 10 or placebo. J Rheumatol. 1999;26(10):2089-93.

86. Cunnane G, Madigan A, Murphy E, FitzGerald O, Bresnihan B. The effects of treatment with interleukin-1 receptor antagonist on the inflamed synovial membrane in rheumatoid arthritis. Rheumatology. 2001;40(1):62-9.

87. Smeets TJ, Dayer JM, Kraan MC, Versendaal J, Chicheportiche R, Breedveld FC, Tak PP. The effects of interferon-beta treatment of synovial inflammation and expression of metalloproteinases in patients with rheumatoid arthritis. Arthritis Rheum. 2000;43(2):270-4.

88. van der Pouw Kraan TC, Wijbrandts CA, van Baarsen LG, Rustenburg F, Baggen JM, Verweij CL, Tak PP. Responsiveness to anti-tumour necrosis factor alpha therapy is related to pre-treatment tissue inflammation levels in rheumatoid arthritis patients. Ann Rheum Dis. 2008;67(4):563-6.

89. Hogan VE, Holweg CT, Choy DF, Kummerfeld SK, Hackney JA, Teng YK, Townsend MJ, van Laar JM. Pretreatment synovial transcriptional profile is associated with early and late clinical response in rheumatoid arthritis patients treated with rituximab. Ann Rheum Dis. 2012;71(11):1888-94. 